\title{
WPS 3052
}

\section{Policy Research Working Paper 3052}

\section{Long-Run Impacts of China's WTO Accession on Farm-Nonfarm Income Inequality and Rural Poverty}

Kym Anderson Jikun Huang

Elena Ianchovichina

The World Bank

Poverty Reduction and Economic Management Network Economic Policy Division 


\section{Abstract}

Many fear China's accession to the World Trade Organization (WTO) will impoverish its rural people by way of greater import compettion in its agricultural markets. Anderson, Huang, and Ianchovichina explore that possibility bearing in mind that, even if producer prices of some (land-intensive) farm products fall, prices of other (labor-intensive) farm products could rise. Also, the removal of restrictions on exports of textles and clothing could boost town and village enterprises, so demand for unskilled labor for nonfarm work in rural areas may grow even if demand for farm labor in aggregate falls. New estimates, from the global economywide numerical simulation model known as GTAP, of the likely changes in agricultural and other product prices as a result of WTO accession are drawn on to examine empirically the factor reward implications of China's WTO accession. The results suggest farmnonfarm and Western-Eastern income inequality may well rise in China but rural-urban income inequality need not. The authors conclude with some policy suggestions for alleviating any pockets of farm household poverty that may emerge as a result of WTO accession.

This paper-a product of the Economic Policy Division, Poverty Reduction and Economic Management Network-is part of a larger effort in the network to assess the impact of China's WTO accession. Copies of the paper are available free from the World Bank, 1818 H Street NW, Washington, DC 20433. Please contact Sarah Lipscomb, room MC4-404, telephone 202-458-7266, fax 202-522-2530, emall address slıpscomb@worldbank.org. Policy Research Workıng Papers are also posted on the Web at http://econ.worldbank.org. The authors may be contacted at k.anderson@adelaide.edu.au, jikhuang@public.bta.net.cn, or eianchovichina@worldbank.org. May 2003. (33 pages)

The Policy Research Working Paper Senes disseminates the findings of work in progress to encourage the exchange of tdeas about development issues. An objective of the series is to get the findings out quickly, even if the presentations are less than fully polished. The papers carry the names of the authors and should be cited accordingly. The findings, interpretations, and conclusions expressed in this paper are enttrely those of the authors. They do not necessanly represent the vtew of the World Bank, its Executtve Directors, or the countnes they represent. 


\title{
Long-Run Impacts of China's WTO Accession on Farm-Nonfarm Income Inequality and Rural Poverty*
}

\author{
Kym Anderson, ${ }^{\dagger}$ Jikun Huang, $^{\ddagger}$ and Elena Ianchovichina ${ }^{\S}$
}

Key words: WTO accession, China's economic reform, rural-urban income inequality

JEL codes: F14, O19, O53

\footnotetext{
"The paper was presented at the World Bank's Conference on China's WTO Accession, Policy Reform, and Poverty Alleviation, Beijing, 28-29 June 2002, the $5^{\text {th }}$ Conference on Global Economic Analysis, Taipei, 5-7 June 2002, the AARES Pre-Conference Workshop on WTO: Issues for Developing Countries, Canberra, 12 February 2002, and the International Agricultural Trade Research Consortium's conference on Globalization, Biotechnology, and Trade, Tucson, 14-16 December 2001. Thanks are due to the World Bank and Australian Research Council for financial support, and to Will Martin, Tom Hertel, Scott Rozelle, and other participants in the World Bank's project for helpful comments on earlier versions of this paper.

${ }^{\dagger}$ School of Economics and Centre for International Economic Studies, University of Adelaide, Adelarde SA 5005 Australia, phone (+61 8) 8303 4712, fax (+61 8) 8223 1460, kym.anderson@adelaide.edu.au.

$\ddagger$ Center for Chinese Agricultural Policy, Chinese Academy of Sciences, Beijing, China, phone (+86 10) 64889440 , fax (+86 10)64856533, jikhuang@public.bta.net.cn.

${ }^{8}$ Poverty Reduction and Economic Management, Economic Policy, World Bank, Washington, D.C., USA, Phone (+1 202) 458 8910,Fax (+1 202) 522 2530, eianchovichina@worldbank.org.
} 



\title{
Long-run Impacts of China's WTO Accession on Farm- Nonfarm Income Inequality and Rural Poverty
}

\author{
Kym Anderson, Jikun Huang and Elena Ianchovichina
}

After fifteen years of negotiations, China acceded to the WTO at the end of 2001. During those negotiations, China was continually opening up its economy. However, substantial economic policy reform is still needed before the transition from plan to market is complete. Some of those remaining reforms will be introduced over the next few years to fulfill the legal obligations China has committed to in its WTO Protocol of Accession.

Keeping the momentum of growth-enhancing trade reform going requires convincing sceptics that there will not be significant losers. Yet such reform necessarily involves structural adjustments by households, firms and bureaucracies. While the economy as a whole can gain substantially from those adjustments, ${ }^{1}$ losses and even hardship can result for some households unless complementary domestic policies are in place to facilitate adjustment and/or compensate losers. That underscores the importance of first analyzing the likely distributional consequences of the reforms themselves, and then considering what complementary policies are needed to provide adequate safety nets for potential losers. Of particular concern in China's case is that farm incomes may fall, exacerbating the rise since the mid-1980s in farm-nonfarm and inlandcoastal aggregate income inequality and possibly reversing the decline since the late $1970 \mathrm{~s}$ in rural poverty (see Kanbur and Zhang 2001).

The policy changes still to be made to fulfill WTO obligations will affect all areas of China's economy. Numerous commentators predict a dramatic effect on agriculture and hence rural areas, because the reforms in China over much of the past quarter-century bypassed the country's trade policies for key farm products. Before acceding to WTO, China was required by its trading partners to commit to major changes in those farm trade policies by 2005 - protection cuts that appear far greater, and faster, than any other developing country was required to commit to in the Uruguay Round Agreement on Agriculture. With one-quarter of rural households in China living on less than $\$ 1$ a day in 1999 (c.f. 1 per cent of urban households) 
such that more than three-quarters of all poor Chinese people live in rural areas, concerns about the impact of WTO accession on poverty alleviation are understandable.

Meeting the commitments in agriculture will directly affect China's farm sector plus its food, feed and fiber processors, as well as consumers of food and beverages. Imports of numerous land-intensive farm products may increase, and most observers presume that will put downward pressure on prices received by China's farmers. However, reduced protectionism may boost output and exports of some labor-intensive farm products in which China still has a comparative advantage. ${ }^{2}$ In addition, farm households will be affected indirectly by many of the other commitments China has made in its WTO Accession Protocol. Especially important will be the arrangements for phasing out the 'voluntary' export restraints on China's textile and clothing trade, and the reductions in protection of the motor vehicles and parts industry. So too will be the myriad commitments affecting the services sector, including state trading enterprises. Those changes, together with the promised increase in a wide range of agricultural imports, will allow China to exploit more fully its strong comparative advantage in unskilled labor-intensive products - both farm and non-farm (Anderson 1990, 1992; Huang et al. 2000).

To assess the long run impact on farmer incomes and on rural areas of the remaining reforms required to meet China's commitments to the WTO membership, it is necessary to see those changes in the context of on-going economic growth and structural change. This paper therefore begins with a brief summary of rural developments since the initial reforms began in the late 1970s, of recent policies affecting rural households, and of pertinent reforms still to be delivered as part of China's WTO commitments. With that background, the paper then provides some indication of the likely effects on the welfare of different factor markets and hence different types of households of the reforms to be implemented between 2002 and 2007. Even the direction, let alone the magnitude, of some of the effects cannot be discerned from theory (Winters 2000; McCulloch, Winters and Cirera 2001), so we use the numerical simulation model known as GTAP to address these issues. The paper concludes by drawing out implications for Chinese policy makers wishing to pre-empt any increases in food insecurity or rural poverty.

\footnotetext{
${ }^{1}$ Although national gains from trade are not guaranteed while there are major domestic policy distortions in place, such as in the labor market. See, for example, Krishna and Yavas (2002).

2 The difficulties China has had in exporting food products to, for example, Japan, Korea and the United Kingdom in the past year or so because of those countries' quarantine/SPS measures should ease following WTO accession, or at least be challengeable under WTO Dispute Settlement provisions. They are ignored in the empirical analysis below, as is the possibility that China itself may use quarantine measures to limit its imports of farm products.
} 


\section{The setting}

\section{Rural developments since the late 1970s}

The unilateral decision in December 1978 to open up the Chinese economy was a major stimulus to economic growth: the pre-reform rate of per capita GDP growth of 3.1 per cent per year more than doubled, and has remained above 7 per cent for the past two decades (final row of Table 1). Rapid economic growth is normally accompanied by a relative decline in the farm sector, but in China that was initially tempered by the introduction of the farm household responsibility system (which led to the replacement of collective farms with individually managed holdings), and by the raising of prices received by farmers. So began the process of moving away from the taxing of agriculture relative to other sectors - a process followed by most of the advanced economies in the early stages of their industrialization (Anderson and Hayami 1986; Lindert 1991).

Agriculture grew nearly as rapidly as industry from 1979 to 1984 . However, the one-off efficiency effects of moving to the household responsibility system and raising relative prices for farm products were mostly reaped by the mid-1980s, after which agriculture grew at only onethird the pace of industry and less than half that of the service sector as industrialization boomed on the eastern seaboard (Table 1). Employment, output and exports of rural township and village enterprises, meanwhile, have boomed (Table 2). Despite that, migration of farm workers to rural industrial and service activities (not to mention the temporary migration to urban jobs such as in construction), the average farm size and the share of farm household income from farming have fallen steadily since the late 1970s (final two columns of Table 2). Table 3 shows the slowdown in the decline in agriculture's shares of GDP and employment in the 1980s, and its subsequent acceleration in the 1990 s.

Income growth has boosted the demand for foods that are high in protein and nutrients relative to those high in carbohydrates, which has stimulated major structural changes within agriculture as farmers responded to changes in domestic demand. For example, livestock and fish increased their share of agricultural output from less that one-fifth in the late 1970s to two-fifths by the late 1990s (Table 3), while within the crop sub-sector, fruit and vegetable production grew two to three times as fast as grain output (Table 1). The prices and marketing of grain and oilseed products have continued to be highly regulated, whereas markets for horticultural, livestock and fish products have been greatly liberalized. This has accentuated the growth in output of the latter group relative to grain and oilseed output since the mid-1980s (Table 1). Meanwhile, the 
direct consumption of grain by rural as well as urban households has virtually ceased growing (Table 4) -- a consequence not only of incomes rising but also of population growth slowing to less than 1 percent per year and of cuts in the implicit consumption subsidy for foodgrains.

The use of grain for animal feeds continues to grow. To date that has been supplied almost completely by rising domestic production, such that the trend level of grain self sufficiency has remained close to 100 per cent. Table 5 shows that there are nonetheless . considerable changes from year to year in grain exports and imports. It also shows that, overall, China has remained a net exporter of food and feed, with meat, fish, fruit and vegetables providing most of the growth in net export eamings. However, soybean imports grew substantially when the government (in anticipation of WTO accession) lowered the tariff from 114 per cent to 3 per cent in 2000 .

\section{Recent and prospective policies affecting rural areas}

As in most developing countries, ${ }^{3}$ agriculture in China was squeezed at early stages of industrialization with gross fiscal contributions to the sector being more than outweighed by implicit taxation in the form of depressed prices for farm products, neglect of public infrastructure in rural relative to urban areas, and capital outflows via the financial system (Huang and $\mathrm{Ma}$ 1998). Then price and other market reforms associated with China's policy shift from a socialist to a market-oriented economy began to be introduced, starting with non-strategic commodities such as vegetables, fruit, fish, livestock, and oil and sugar crops. The aims of the early reforms were to raise farm level prices and gradually deregulate the market. As the right to private trading was extended to include surplus output of all categories of agricultural products after contractual obligations to the state were fulfilled, the foundations of the state marketing system began to be undermined (Rozelle et al. 1997). Despite periodic stop-go cycles in the reform process, the proportion of retail commodities sold at market prices has kept rising. According to Lardy (2001), the share for agriculture was just 6 per cent in 1978 but had risen to 40 per cent by 1985,79 per cent by 1995 and 83 per cent by 1999.

What have these policies meant for nominal rates of agricultural protection in China (the percentage by which domestic prices exceed prices at the country's border)? Table 6 shows new estimates of nominal protection rates for key agricultural commodities for some recent years. It

\footnotetext{
${ }^{3}$ See Sah and Stiglitz (1992) and Anderson (1995).
} 
suggests rice, meat, fish and fruit and vegetables have been priced at less than border prices while other grains, oilseeds, sugar, cotton and milk have been priced at one-fifth to two-fifths above border prices. Maize and cotton also enjoyed export subsidies in 2001 (amounting to onethird and one-tenth of f.o.b. prices, respectively).

Table 6 also shows what China has committed to in its WTO Protocol of Accession: tariff rate quota will apply to grains, sugar and cotton for which out-of-quota tariffs are quite high, but otherwise, after the phase-in period, the tariffs range between just 1 and 15 per cent representing substantial liberalizations over 2001 levels. As well, producers of major crops may continue to be affected by commodity-specific policies of government procurement of a portion of the crop at lower than market prices (as in the past - see Sicular 1988) or at higher than market prices (as in 1998 - see Huang 1998 and Lu 1999).

What will those reforms mean for agricultural trade? Many analysts have been expecting China to become ever-more dependent on agricultural imports in the course of the economy's rapid industrialization over the past two-plus decades. Some extremists (e.g., Brown 1995) have even suggested China could seriously deprive other developing countries of food. Yet as reported above, net food import growth has not yet happened, at least not in a sustained way, and China has continued to be a net exporter of meat, fish, fruit and vegetables. Indeed on occasions in the latter 1990s, China also was a net exporter of grain and cotton (Table 5). How much of that is due to government policies that constrained domestic demand, including occasional export subsidies, is a moot point.

In its WTO Protocol of Accession, China has agreed to have no agricultural export subsidies, and to limit its domestic support to farmers to $8.5 \%$ of the value of production (compared with $10 \%$ for other developing countries). The import market access commitments China has made to WTO members look substantial on paper. Tariff rate quotas will be retained only on wheat, rice, maize, edible oils, sugar, cotton and wool, domestic production of which in aggregate comprises only about one-sixth of China's agricultural GDP. The quota volumes are to grow over the next three years at annual rates ranging from 5 to 19 per cent. A further commitment by China is that state trading monopolies will disappear (except for tobacco): even though some state trading enterprises will continue to operate, there will be competition from private firms in the importing and exporting of farm products, at least within the tariff-ratequotas. 
Farmers and the rural sector more broadly will be affected also by China's commitment to provide improved and WTO-bound market access for industrial products. Mineral and manufacturing tariffs will be bound and generally reduced on a broad basis, with many tariffs falling to $10 \%$ or less. Tariffs will be cut on accession and further cuts will be phased in by 2005 (with just a few exceptions). Furthermore, for industrial products, China will reduce significantly its non-tariff measures and eliminate all quotas, tendering and import licensing on non-farm merchandise by no later than 2005. Quotas on Chinese imports of automobiles and parts will grow by $15 \%$ annually from a level of around US $\$ 6$ billion in 2000 , and these quotas will be eliminated by 2005 . For textiles and clothing, however, the current 'voluntary' export restraints will not be completely phased out until the end of 2008 . Substantial commitments to open up services markets in China also have been made.

Over the 1990s the average scheduled tariff rates for manufacturing initially exceeded but fell more than for agriculture, and by 2005 the manufacturing average will be well below that for agriculture (a simple average of 7 per cent, versus 17 per cent for agriculture). That does not give a true indication of the extent of change in protection that is taking place, though, because in the 1990s many manufactures have been entering China at reduced or zero tariffs via duty drawbacks, to encourage foreign investment in processing of imported intermediate goods for subsequent export. Some agricultural products also have entered at less than the scheduled rate, including through smuggling.

What all this means for incentives for each industry is difficult to discern precisely, but it provides better information than has been available to date for analysing empirically the economic effects of the reforms associated with China's WTO accession, including the impact on factor rewards and prices from which inferences about income distributional effects can be made. We do this bearing in mind the marked differences in per capita incomes between eastern, central and western provinces, and between urban and rural areas (as shown in Tables 7 and 8, and in Kanbur and Zhang 2001). 


\section{Applying the GTAP model}

Version 5 of the computable general equilibrium model of the global economy known as GTAP is used here. ${ }^{4}$ Being an economy-wide model, GTAP describes both the vertical and horizontal linkages between all product markets within the model's individual countries and regions as well as between countries and regions via their bilateral trade flows. For present purposes the 1997 data base is aggregated to 25 sectors and 20 regions and projected forward first to 2001 and then to 2007, using World Bank projections of population, income, and factor endowments (see Appendix Table A). The initial base case assumes China retains its protection policies as of 1995 and Taiwan retains its protection as of 1997, but that all other countries fully implement their Uruguay Round obligations on schedule before 2005. China's trade policy changes between 1995 and 2001 are assumed to have been in anticipation of the requirements of, and hence part of, China's WTO accession. These are analyzed in detail in Ianchovichina and Martin (2002), together with the effects of implementing over the next few years the remainder of China's commitments as recorded in its WTO Protocol of Accession. ${ }^{5}$ In this paper we focus on just the additional reform commitments to be implemented after 2001 (relative to the revised base case in which China's reforms only up to 2001 are in place and there are no further reforms to 2007). For key agricultural import policies these remaining reform commitments are assumed to shift nominal rates of protection (NRPs) from column 3 to column 6 of Table 6 . As well, the export subsidies in place in 2001 ( 34 per cent for maize, 10 per cent for cotton) are to be eliminated, and we assume no new farm production subsidies are introduced. ${ }^{6}$ The choices of new agricultural NRPs fall into three categories: no change if they were negative in 2001 (rice, meats, vegetables and fruits), a move to part-way between the in-quota and out-of-quota tariffs if the TRQs bite

\footnotetext{
${ }^{4}$ The GTAP (Global Trade Analysis Project) model is a multi-regional, static, applied general equilibrium model based on neo-classical microeconomic theory including full employment of all factors of production, constant returns to scale and perfect competition. See Hertel (1997) for comprehensive documentation. The Version 5 data base is described at www.gtap.org. The model is solved with GEMPACK software, described in Harrison and Pearson (1996).

${ }^{5}$ A particularly important feature of their analysis is the inclusion of China's duty exemptions in the base scenario, because otherwise the model would overstate the gains from tariff reductions. Tariff cuts are from 2001 applied rates to post-accession bound rates (or zero if the latter exceed the former). In this application the aggregate trade balance and government tax revenue are both assumed to remain a fixed share of GDP. The 2001 trade data are from COMTRADE, and the 2001 applied tariffs for China are from CDS Consulting Co. (2002).

${ }^{6}$ Three non-farm reforms of importance are worthy of mention. The 'voluntary' export restraint on China's textile and clothing exports to the U.S. and EU, expressed in the base scenario as taxes on those exports, are removed; restructuring of the motor vehicles and parts industry following WTO accession is modelled as a 20 per cent productivity boost to vehicle assembly, following Francois (2002); and liberalization of China's services trade also follows Francois (2002).
} 
(wheat, coarse grains, cotton), and otherwise a move to the new in-quota tariffs (oilseeds, sugar, milk). Sensitivity of the results conceming the first two categories are explored in the qualifications section, however.

If this reform were to require a movement of unskilled labor out of farm activities, three impediments need to be kept in mind. One is that those farm workers would be less than perfect substitutes for those already in non-farm pursuits. Econometric work by Sicular and Zhao (2002a) suggested that restraints on mobility could be approximated via a CET function with an elasticity of transformation of 1.3 . $^{7}$ We have therefore incorporated that in the GTAP model for China. Another impediment to off-farm migration is that urban social welfare benefits such as subsidies to housing, food, education and health care are not available to non-urban people, except by purchasing a residence permit, or hukou (Zhao 1999). And the third impediment is that farm workers who permanently cut their ties with the rural sector may lose entitlement to returns from their family's land, and even the direct support and assistance of family members (Hussain 2001). These latter two impediments have contributed to the persistence of a very large gap in farm versus non-farm returns to unskilled labor. After adjusting for differences in work effort, the analysis by Shi Xinzheng (2002) allows us to estimate that roughly one-third of the gap between urban and rural unskilled wages can be explained by the registration variable and differences in the cost of living. ${ }^{8}$ We have assumed that gap will persist even if workers do move off the farm in the initial simulation (although the sensitivity of the results to that assumption is explored in the qualifications section).

The closure adopted here is a long-run one in which, in addition to the above assumptions about farm labor, nonfarm labor is mobile between nonfarm sectors, capital is mobile between sectors, and agricultural land is mobile between industries within the agricultural sector. This closure differs from the short -run closure used by Chen and Ravallion (2002), where a large number of households is examined, based on current occupational classes. With these modifications to the GTAP model, what results emerge from implementing after 2001 the remainder of China's commitments to WTO members? Here we focus on comparing farm versus non-farm results. This is not quite the same as rural versus urban, given the large and growing

\footnotetext{
${ }^{7}$ In a subsequent analysis, Sicular and Zhao $(2002 \mathrm{~b}$ ) provide estimates of 2.67 for the "push" elasticity of transformation from changes in agricultural returns to changes in the supply of labor out of agriculture but only 0.6 from changes in non-agricultural returns. Ianchovichina and Martin (2002) conducted sensitivity analysis on the implications of changes in these parameters.
} 
amount of non-farm rural activities (Table 2), but it is the best we can do with the GTAP model which does not distinguish activities by location within a country. ${ }^{9}$

\section{What results can we anticipate?}

In a recent paper, Carter and Estrin (2001) develop a model with two sectors, agriculture and non-agriculture, that assumes capital is sector-specific and labor is intersectorally mobile. They assume the trade reform from China's WTO accession will lower the relative price of non-farm goods (larger tariff cuts for non-farm than farm products). If the economy started from equilibrium in the labor market, that price change would lower labor's wage in terms of farm goods and would cause labor to migrate from non-farm to farm activities. If, however, the economy starts from a situation in which farm workers face impediments to migrating to nonfarm employment, the wage in the non-farm sector would have exceeded that in agriculture. In that case, a fall in the relative price of non-farm products would lower the non-farm wage without changing the low farm wage (if both are again measured in terms of agricultural goods). If the government were to simultaneously remove the barrier to out-migration of farm labor, another welfare gain would accrue to the overall economy. Farm workers would benefit from trade reform alone in so far as they consume non-farm products whose price is lower after that policy change. They would benefit even more if the restraint on their migration were to be lifted. Non-farm workers, however, would suffer wage cuts in terms of farm products from each of those two policy changes, cuts that may offset the fall in the price of non-farm products they consume. Carter and Estrin therefore conclude that China's rural-urban income inequality (at least for laborers) would be reduced from further trade liberalization and more so if the current policies that inhibit off-farm migration were relaxed.

Neat though the Carter/Estrin analysis is, it ignores the differences between skilled, unskilled non-farm and unskilled farm workers. Also, its assumption that the incentive to produce non-farm relative to farm products will fall following WTO accession needs to be tested, since there will be some positive and some negative changes to the price of both sets of highly tradable products. Furthermore, the demand for difficult-to-trade products will rise following the income gains from trade reform, and their cost of production will change. Does the

\footnotetext{
${ }^{8}$ Of this, 28 percent is explained by the registration dummy variable, and 6.5 percent by differences in living costs.

${ }^{9}$ For a more-detailed breakdown showing both farm and non-farm rural households, see Hertel, Zhai and Wang (2002).
} 
Carter and Estrin conclusion, that WTO accession will reduce rural-urban income inequality, hold up when account is taken of these facts in a detailed empirical model such as GTAP? And how would poverty be affected, bearing in mind that there are considerable differences between the production structures and per capita incomes of western, central and eastern provinces (Table 7), rural incomes are only one-third of urban ones (Table 8), and 85 per cent of rural households in the bottom quartile of the income distribution are agricultural (Sicular and ZThao 2002a)?

What do the resullts show?

Our analysis begins with the core accession scenario, and then is followed by three variations on that core scenario.

\section{The core WTO accession scenario}

To begin with the bottom line of the main scenario before revealing the details, the core empirical results suggest increases in farm-nonfarm income inequality. The main reason for this is that opposite to the conclusion of Carter and Estrin the GTAP model suggests the relative producer prices of farm products will fall more than the prices of labor intensive non-farm products following the completion of WTO accession reforms (Table 9). Relative prices are lower for labor intensive non-farm products compared with what they would be without those remaining reforms -- despite the removal of the 'voluntary' export restraint on sales of those products to the U.S. and European Union - for three reasons: because the demand for labor on farms is lower which lowers the cost of unskilled labor in manufacturing, because import taxes on the intermediate inputs used in those manufacturing activities are lower due to the accession process, and because the real exchange rate effect of the tariff reductions lowers the cost of nontraded goods and other factors used as inputs in production.

The lower cost structure in unskilled labor intensive manufacturing activities by 2007 causes the quantity of unskilled non-farm labor demanded to be greater (by 0.8 per cent); but lower farm product prices mean the quantity of unskilled farm labor demanded is less (by 1.7 per cent). A consequence of the reform is a 0.7 per cent fall in the real wage for unskilled farm labor, and a rise in real wages for unskilled non-farm labor of 1.2 per cent (after adjusting for the 
change in the aggregate cost of living). ${ }^{10}$ Farmers are also made worse off by the lower demand for farm land, the return from which is 5.5 per cent lower in 2007 following WTO accession reforms. Meanwhile, the real wages of skilled labor increase by 0.8 per cent, and the rewards to non-farm capital are 1.3 per cent higher. Together these results suggest the owners of non-farm capital gain almost the same in proportional terms as unskilled laborers in non-farm employment, but the latter do better than skilled workers. Hence on balance income inequality may improve slightly among non-farm households dependent mainly on labor income. ${ }^{11}$

However, income distribution can be expected to worsen as between farm and non-farm households, although the degree depends on the proportion of farm household income earned off the farm. With only 1.7 per cent of (or about 6 million) unskilled farm workers leaving agriculture for non-farm work (because of the assumed impediments to out-migration), and with land returns depressed by 5.5 per cent in addition to farm labor returns being 0.7 per cent lower, the gap between farm and non-farm incomes even within rural areas, and certainly between rural and urban areas, looks set to rise slightly unless remedial policy action is forthcoming. For farm households entirely dependent on earnings from agriculture (type A in Table 10), income would fall 1.6 per cent on average. This would differ little across the three regions identified in Table 7 , since product shares for farm output - when fish products are ignored - are reasonably similar in western, central and eastern provinces. ${ }^{12}$ For farm households earning 30 per cent of their income from nonfarm unskilled work, however, that income fall is only half as large ( 0.8 per cent); and for farm households earning 60 per cent of their income from nonfarm unskilled work, their incomes would not decline at all (types B and C in Table 10 -- see rows 7 and 8).

Sectoral details of the GTAP results are summarized in Table 9. Real consumer prices are lowered most by WTO accession for motor vehicles, oilseeds and sugar (and for beverages and tobacco, although if China was using import taxes on those items as a form of consumption tax and their decline were to be matched by an increase in domestic sales taxation, those price

\footnotetext{
${ }^{10}$ The present version of the GTAP model has only one aggregate household, so it cannot distinguish between the different consumption bundles and factor endowments of different types of households. Throughout, real price changes refer to the change in price relative to the consumer price index change, given the consumption bundle of the aggregate household.

${ }^{11}$ Wages of skilled workers might increase more than suggested here as we do not capture the endogenous productivity growth resulting from the substantial liberalization of the service sectors.

${ }_{2}^{2}$ However, if we look at northern and southern provinces in China, differences could be large since wheat, maize, soybean and cotton are planted primarily in northern China, while rice, horticulture, livestock and fish are raised mostly in southern China.
} 
declines may not materialize). They are also lowered for textile products and to a lesser extent clothing. Among the farm products, consumer prices are raised slightly for livestock products, somewhat more for grains, and significantly for cotton (plant-based fibres). Producer prices are down more for farm products than for most other products except autos though, and farm output is down for all but cotton and meat. Moreover, feedgrain exports shrink by three-quarters and cotton exports by half with the abolition of export subsidies. The difference in the effects on production and consumption shown in Table 9 reveal that China's food, feed and fibre selfsufficiency will be reduced at least slightly by these reforms. But the extent is really quite minor: the trade balance column in Table 9 suggests that for all agricultural and food products, net imports would be greater because of the remaining accession reforms by only $\$ 3.96$ billion per year by 2007 (in 1997 US dollars), which represents only 1 per cent of total imports.

The above results depend as always on the assumptions in the model. To check the sensitivity of some of those assumptions, three alternative scenarios were run to compare their results with those in the base accession scenario: greater agricultural protection cuts; removing negative agricultural protection; and removing the wedge between farm and non-farm wages.

\section{Alternative scenario 1: greater agricultural protection cuts}

What if the grain, sugar and cotton NRPs were to drop to the in-quota tariff levels shown in Table 6, for example? An additional GTAP simulation was run and the differences for factor rewards are not huge in aggregate but they would be in the direction of worsening income inequality: unskilled farm wages would fall 0.9 instead of 0.7 per cent and rewards to farm land would fall 6.4 instead of 5.5 per cent on the one hand, while on the other non-farm wages would rise 1.4 instead of 1.2 per cent for the unskilled and 1.0 instead of 0.8 per cent for skilled workers (Table 10). These changes would attract only another million workers from farms, given the assumed impediments of off-farm migration. But while agricultural incomes would be lower,

farm household income would not fall if at least 60 per cent of its income came from wages of non-farm unskilled labor (see row 8 of Table 10). Domestic production of grains, sugar and cotton would be less though, and domestic consumption greater, so self-sufficiency in those products would be slightly lower. Even so, net imports of all food and agricultural products would be greater by only $\$ 1.5$ billion per year by 2007 ( $\$ 5.43$ instead of $\$ 3.96$ billion). Such an import increase would be within the tariff rate quotas for those items with the possible exception 
of maize (depending on the extent to which other feedgrains that are not TRQ-restricted, such as barley, are substitutable for maize). National economic welfare would be only very slightly greater in this case as compared with the core scenario (see bottom row of Table 10).

\section{Alternative scenario 2: removing negative agricultural protection}

If the negative NRPs for rice, meats, vegetables and fruits were to be raised to zero, the income distributional effects would go in the opposite direction to those in the previous alternative scenario (less inequality between farm and non-farm households). The changes are not great though, even though these products account for nearly 40 per cent of the value of food and agricultural output in China. As can be seen by comparing columns 1,2 and 3 of Table 10, they would involve about as much improvement in income distribution as the previous alternative scenario would worsen it. This case involves a 3 per cent larger national economic welfare gain than the core case (bottom row of Table 10).

\section{Alternative scenario 3: removing the wedge between farm and non-farm wages}

If one expected all off-farm migrants to go to rural rather than urban non-farm jobs, and if those migrants were just as adept at such non-farm work (e.g., because they are young or even just school-leavers and hence no different from other new entrants to unskilled rural non-farm work), the assumption above of a one-third wedge between farm and non-farm wages for the unskilled could be dropped. ${ }^{13}$ Rerunning the model without that assumed wedge has significant impacts on the estimated number of farm workers moving to non-farm employment and on the industry composition of China's economy. Approximately 28 million people would leave their farm jobs as a result of accession if that barrier to farm out-migration was removed, compared with the estimated 6 or 7 million people mentioned above when the hukou system remains in place.

The impact on industry composition of removing that labor market distortion is substantial. WTO accession will have a much stronger positive impact on China's manufacturing and service sectors if the hukou system is abolished. This will allow more production of metals, automobiles and electronic equipment, and more services. That is possible in this scenario because factor use in farming and hence agricultural output are less, which also means more imports of food and agricultural products are needed ( $\$ 10.2$ billion by 2007 instead of the $\$ 3.96$ in the core scenario).

\footnotetext{
${ }^{13}$ Evidence of increased flexibility in China's labor markets in recent times is presented in Lohmar (2001).
} 
The consequences for income distribution are dramatic. Table 10 shows that this greater offfarm migration of workers would cause earnings of farm workers (mostly self-employed farmers) to rise because of WTO accession by 16.8 per cent, instead of falling by 0.7 per cent as in the core accession scenario. Even though the reduced demand for land would cause its rental value to fall more (9.7 instead of 5.5 per cent), the farmers' overall earnings from agriculture would be 6.8 per cent greater in this scenario - in stark contrast to the core scenario where they fall. True, the earnings of all other factor owners fall in this scenario, particularly unskilled nonfarm labor (by 3.8 per cent). However, given that farmers are among the country's poorest households, this scenario suggests that WTO accession would reduce income inequality and poverty if the labor market distortion associated with the hukou system were to be reformed. It also suggests that the boost to national economic welfare in aggregate could be greater if WTO accession were to be accompanied by labor market reform: $\$ 11$ billion per year instead of just the $\$ 9.6$ billion in the core accession scenario.

\section{Comclusions amd pollicy implincations}

The assumption in GTAP that all households are identical in their consumption patterns is of course a fiction. They differ as between urban and rural areas, between farm and non-farm households within rural areas, and within each of those groupings according to region and income level. Post-simulation analysis at that level of detail for the short run is provided in Chen and Ravallion (2002). But even without that detail, it is possible to draw some broad conclusions about the long run implications of WTO accession for agriculture and for income distribution.

Our initial analysis assuming no reform of the hukou system affecting labor market suggests rural non-farm incomes will rise on average absolutely and possibly even relative to urban incomes in the case of households depending just on labor income (assuming urban laborers are more skilled). However, some farm households facing increased import competition may be worse off in this case, ceteris paribus, if they are:

- unable to send household members to jobs in expanding industrial and service industries;

- are too poorly served with infrastructure to attract such activities to their own region;

- are unable to diversify into producing farm goods whose relative price has risen; and/or

- do not have relatives able to repatriate non-farm earnings to them. 
Thus in the core scenario the incidence of rural non-farm poverty will fall mainly because of the growth in wages for unskilled workers in rural non-farm activities, while poverty may well increase in agriculturally based hinterland provinces a long way from markets and in regions poorly served with the necessary infrastructure to attract investment in such expanding activities as textiles and clothing.

The first alternative scenario shows that this situation would be exacerbated slightly if the TRQ-protected items (grains, sugar and cotton) were to become even less protected than we initially assumed. By way of contrast, the second alternative scenario suggests the situation could be made slightly less extreme by removing the negative protection affecting rice, meats, vegetables and fruits. But both of these alternatives only involve small changes to the magnitudes of effects, rather than altering the sign of those effects, and both add only a small amount to the aggregate gains from trade liberalization.

What the third alternative scenario makes clear, by way of contrast, is that the sign of the effects could be switched to favor the poorer farm households - albeit at the expense of the richer non-farm ones - if the remaining WTO accession were to be accompanied by reform of the hukou system that allowed some members of those households to obtain higher-paying nonfarm employment and repatriate earnings back to their farm family. ${ }^{14}$ And this case would involve a national economic welfare gain that is one-sixth above that in the core scenario without labor market reform.

National self-sufficiency in food, feed and fiber will fall somewhat, particularly as demand for livestock products grows with income gains from trade reform and as production of natural fibre-based textiles and clothing expand. But overall, most of these self-sufficiency effects of the remaining reforms that are required following WTO accession are relatively very small in magnitude. ${ }^{15}$ They would be largest in the third alternative case where labor market distortions are also removed. That is not to say food security would fall in that case though. It is changes in incomes of the poor, and hence in their capacity to purchase food, that affect food

\footnotetext{
${ }^{14}$ These alternatıve results for the long run complement the findings of Chen and Ravallion (2002) for the short-run. What they underscore is that whether a particular group gains or loses from a shock such as WTO accession in the long run depends heavily on their sources of household income and their capacity to adapt to the changed economic circumstances.

${ }_{15}$ They are especially small when compared with the changes that are taking place in the course of normal economic growth, as shown retrospectively in Tables 1-5 above and prospectively in earlier analyses by Anderson et al. (1997a, b) and in Ianchovichına and Martin (2002).
} 
security, and in that third alternative scenario the poorest aggregate group (farm households that had been heavily dependent on agriculture) would gain most.

What else should be done if the labor market were not to be reformed? If in that case some farmers' incomes are to worsen relative to those of non-farm households, and if there is concern about the fall in agricultural self-sufficiency, it does not follow that trade reform should be abandoned. Rather, first-best ways of dealing with those concerns should be sought (and with any transitory unemployment that might follow reform). The most efficient policy responses are likely to involve investments in rural human capital, rural infrastructure and $\mathbb{R} \& \mathbb{D}$ (Fan, Zhang and Zhang 2002), improvements in the land tenure system and rural financial markets, reductions in informal taxes/levies on farmers by local governments, and changes in grain marketing.

First, the government might consider further investments in basic rural education and health services to reduce the adverse effect of trade reform on poverty incidence and perceived food security. Better education and health for farmers' children not only boosts their farm productivity should they choose to stay on the farm after finishing school; it also increases their capacity to find more-lucrative off-farm work and to adjust to non-agricultural employment and living (Schultz 1975; Zhang et al., 2002). In addition to those longer-term benefits, there could also be an immediate poverty alleviating effect if the government were to cut basic school fees and make up the shortfall with a bigger direct grant to rural primary and middle schools.

Second, improvements in rural infrastructure such as roads and rail mean that a larger share of the price eventually received at the end of the marketing chain for farm products can be passed back to farmers. Such improvements also lower the barrier for off-farm work by members of farm households, making it easier for them to take advantage of expanding employment opportunities in rural townships.

Third, agricultural R\&D can ease both urban and rural poverty (see Fan, Fang and Zhang 2001; Hazell and Haddad 2001). A boost in agricultural productivity could significantly offset the 2-8 per cent drop in agricultural production that is estimated in the core scenario to result from WTO accession. An important policy issue here is whether China should deny itself the use of GMOs in food production. Since our results suggest China would be exporting less food postWTO accession and beyond, there is less sense in banning food GMOs in China if such a ban were to be imposed simply because of fears of otherwise being denied access into food markets abroad (Anderson and Yao 2002; Huang et al., 2002). 
Fourth, improvements in the land tenure system would not only increase the incentive to invest more in land but would also enhance the collateral of farm households. If accompanied by improvements in rural financial markets, investments by farmers back into agriculture would rise. They would rise further if returns were increased via reductions in informal taxes/levies on farmers by local governments.

And fifth, the government might reduce its regulation of grain marketing and in particular cease compulsory procurement from farmers at less than market prices and reduce the provision of grain to urban consumers at less than market prices. De-empahsising the Governors' grain responsibility system (provincial self-sufficiency) would allow more exploitation of comparative advantage within China too.

If all that was considered insufficient support for incomes of the poorest farm households, short-term adjustment assistance via infra-marginal (and hence not output-inducing) producer price subsidies could be provided so as to boost their farm incomes without boosting farm output (in an equal but opposite way to that used to tax farmers in earlier decades -see Sicular 1988). Such an intervention could well be deemed WTO-consistent because of its decoupled nature, and in any case if it was just targeted to poor farmers it is unlikely to ever exceed 8.5 per cent of the value of China's output of the product concerned (its de minimis exemption limit for productspecific support under Article 6.4 of the WTO's Agreement on Agriculture).

Finally, now that China is in the WTO it has the opportunity to take part in new rounds of multilateral trade negotiations, whereby it can seek increased market access for its exports of farm (and other) products abroad. While not taken into account in the present paper, if WTO membership enhances China's chances of expanding its access to agricultural more than other markets abroad in the future, that would be a positive benefit of WTO accession for China's farmers and rural areas. Martin (2002) points out that Chinese farm exports face particularly high barriers abroad, so this potential benefit is non-trivial in principle (although in practice it may be difficult to secure, especially if the main barriers are SPS measures). ${ }^{16}$ That proposition was tested recently by $\mathrm{Yu}$ and Frandsen (2002), also using the GTAP model. They find that reductions in barriers to agricultural imports and in domestic support to farmers in OECD countries reduces the extent to which China's farm output would fall with WTO accession and in 
some cases leads to outputs expanding instead of contracting. As a consequence, China's agricultural imports are reduced slightly and its agricultural exports are greater. These changes are reflected in Table 11: it shows that not only would China's food self-sufficiency be higher with than without agricultural protection in the EU, US and Japan, but that the difference is in most cases more than enough to offset the fall in self sufficiency that is estimated to result from China's WTO accession. Such reform in the OECD would clearly benefit farm households in China, providing a further pro-poor consequence of trade reform.

${ }^{16}$ There is also the question of how China's membership will alter the relative strengths of liberal versus protectionist forces in the next WTO rouna- If multilateral farm trade negotiations. Mathews (2002) argues that China's accession is likely to affect both sides, so the net effect is difficult to discern a priori. 


\section{References}

Anderson, K. (1990), Changing Comparative Advantages in China: Effects on Food, Feed and Fibre Markets, Paris: OECD in English and French (and Beijing: Economic Science Press for the State Planning Commission, 1992 in Chinese).

Anderson, K. (ed.) (1992), New Silk Roads: East Asia and World Textile Markets, Cambridge and New York: Cambridge University Press.

Anderson, K. (1995), "Lobbying Incentives and the Pattern of Protection in Rich and Poor Countries", Economic Development and Cultural Change 43(2): 401-23, January.

Anderson, K., B. Dimaranan, T. Hertel and W. Martin (1997a), "Asia-Pacific Food Markets and Trade in 2005: A Global, Economy-Wide Perspective", Australian Journal of Agricultural and Resource Economics 41(1): 19-44, March.

Anderson, K., B. Dimaranan, T. Hertel and W. Martin (1997b), "Economic Growth and Policy Reforms in the APEC Region: Trade and Welfare Implications by 2005", Asia-Pacific Economic Review 3(1): 1-18, April.

Anderson, K., Y. Hayami and others (1986), The Political Economy of Agricultural Protection: East Asia in International Perspective, Boston, London and Sydney: Allen and Unwin (also available in an expanded Chinese language edition translated by F. Cai, Tianjin: People's Publishing House, 1996).

Anderson, K. and S. Yao (2002), "China, GMOs and World Trade in Agricultural and Textile Products”, Pacific Economics Review (forthcoming).

Brown, L.R. (1995), Who Will Feed China? Wake-up Call for a Small Planet, New York: W.W. Norton.

Carter, C.A. and A. Estrin (2001), "China's Trade Integration and Impacts on Factor Markets", mimeo, University of California, Davis, January.

CDS Consulting Co. (2002), “Applied Tariffs in China, 2001”, Washington, D.C.

Chen, S. and M Ravallion (2002), "Household Welfare Impacts of China's Accession to the WTO" paper for the DRC/World Bank project on WTO Accession and Poverty Reduction in China, World Bank, Washington, D.C., October.

Fan, S., C. Fang and X. Zhang (2001), "How Agricultural Research Affects Urban Poverty in Developing Countries: The Case of China", Environment and Production Technology Discussion Paper 83, IFPRI, Washington, D.C., October. 
Fan, S., L. Zhang and X. Zhang (2002), Growth, Inequality, and Poverty in China: The Role of Public Investments, IFPRI Research Report 125, Washington, D.C.: International Food Policy Research Institute, April.

Francois, J. (2002), "The Motor Vehicle Sector in China and WTO Accession", paper prepared for the DRC/World Bank's Conference on China's WTO Accession and Poverty Alleviation, Beijing, 28-29 June.

Friedman, J. (2000), "Differential Impacts of Trade Liberalization on Indonesia's Poor and Nonpoor", paper presented at the World Bank Conference on International Trade and Poverty, Stockholm, 20 October.

Harrison, W. J. and K. R. Pearson (1996), 'Computing Solutions for Large General Equilibrium Models Using GEMPACK', Computational Economics 9: 83-172.

Hazell, P. and L. Haddad (2001), "Agricultural Research and Poverty Reduction", Food, Agriculture, and the Environment Discussion Paper 34, IFPRI, Washington, D.C., August.

Hertel, T.W. (1997) (ed.), Global Trade Analysis: Modeling and Applications, Cambridge and New York: Cambridge University Press.

Hertel, T.W. (2001), "Assessing the Poverty Consequences of China's WTO Accession", paper outline presented at the first project meeting on WTO Accession, Policy Reform and Poverty Reduction in China, World Bank Resident Mission, Beijing, 6-7 May.

Hertel, T.W., P.V. Preckel, J.A.L. Cranfield and M. Ivanic (2002), "Poverty Impacts of Multilateral Trade Liberalization", paper presented at the $5^{\text {th }}$ Conference on Global Economic Analysis, Taipei, 5-7 June.

Hertel, T., F. Zhai and Z. Wang (2002), "Implications of WTO Accession for Poverty in China", paper for the DRC/World Bank Conference on China's WTO Accession and Poverty Alleviation, Beijing, 28-29 June.

Huang, J. (1998), "Evaluation of Current Three-Grain-Policy", CCAP's Working Paper WP-00C01, Center for Chinese Agricultural Policy, Chinese Academy of Agricultural Sciences, Beijing.

Huang, J. (2001), "Agricultural Policy and Food Security in China", mimeo, Center for Chinese Agricultural Policy, Chinese Academy of Sciences, Beijing.

Huang, J., R. Hu, H. von Meijl and F. von Tongeren (2002). "Biotechnology Boots to Crop Productivity in China and Its Global Impacts", a paper presented at the $5^{\text {th }}$ Conference on Global Economic Analysis, Taipei, 5-7 June 2002.

Huang, J. and H. Ma (1998.), "The 20-Year Reform and the Role of Agriculture in China: Capital Flow from Rural to Urban and from Agriculture to Industry," Reform 5: 56-63. 
Huang, J. and S. Rozelle (2002), "The Nature of Distortions to Agricultural Incentives in China and Implications of WTO Accession", revision (2 April) following its presentation at the second project meeting on WTO Accession and Poverty Reduction in China, World Bank Resident Mission, Beijing, 26-27 October 2001.

Huang, J., S. Rozelle, and L. Zhang (2000), "WTO and Agriculture: Radical Reforms or the Continuation of Gradual Transition", China Economic Review 11: 397-401.

Hussain, A. (2001), "Social Safety Net Policies in China", paper presented at the second project meeting on WTO Accession, Policy Reform and Poverty Reduction in China, World Bank Resident Mission, Beijing, 26-27 October.

Ianchovichina, E. and W. Martin (2002), "Economic Impacts of China's Accession to the WTO", paper for the DRC/World Bank Conference on China's WTO Accession and Poverty Alleviation, Beijing, 28-29 June.

Johnson, D.G. (2001), "The Urban-Rural Disparities in China: Implications for the Future of China", The Second Huang Lian Memorial Lecture, CREDPR, Stanford University, 27 February.

Kanbur, R. and X. Zhang (2001), "Fifty Years of Regional Inequality in China: A Journey Through Evolution, Reform and Openness", CEPR Discussion Paper No. 2887, London: Centre for Economic Policy Research, July.

Krishna, K. and C. Yavas (2002), "When Does Trade Hurt? Market, Transition and Developing Countries", NBER Working Paper 8995, Cambridge MA, June.

Lardy, N. (2001), Integrating China in the Global Economy, Washington, D.C.: Brookings Institution.

Lindert, P. (1991), "Historical Patterns of Agricultural Protection", in Agriculture and the State, edited by P. Timmer, Ithaca: Cornell University Press.

Lohmar, B. (2001), "Changes in Labor, Land and Credit Markets Lead China's Farmers on the Path Toward Modernization", pp. 9-12 in China: Agriculture in Transition, ERS Outlook Report WRS-01-2, edited by H.-H. Hsu and F. Gale, Washington, D.C.: US Department of Agriculture, November.

Lu, F. (1999), “Three Grain Surpluses: Evolution of China's Grain Price and Marketing Policies, 1978-1999", paper presented to the Symposium on China's Agricultural Trade and Policy: Issues, Analysis and Global Consequences, San Francisco, June 25-26, 1999 (http: //aic.ucdavis.edu/research/).

Martin, W. (2002), "Implication of Reform and WTO Accession for China's Agricultural Policies", Economies in Transition (forthcoming). 
Mlathews, A. (2002), "The Possible Impact of China's WTO Accession on the WTO Agricultural Negotiations", The World Economy (forthcoming).

MicCulloch, N., L.A. Winters and X. Cirera (2001), Trade Liberalization and Poverty: A Klandbook, London: Centre for Economic Policy Research.

Rozelle, S., A. Park, J. Ruang and H. Jin (1997), "Liberalization and Rural Market Integration in China," American Joumal of Agricultural Economics 79(2): 635-642, Mlay.

Sah, R. and I.E. Stiglitz (1992), Peasants versus Ciry-Dwellers: Taxation and the Burden of Development, Oxford: Clarendon Press.

Schultz, T.W. (1975), "The Value of the Ability to Deal With Disequilibria", Journal of Economic Literarure 13(3): 827-46, September.

Shi, Xinzheng (2002), 'Empirical Research on Urban-Rural Income Differentials: A Case of China,' mimeo, Peking University.

Sicular, T. (1988), "Plan and Mlarket in China's Agricultural Commerce", Joumal of Political Economy 96(2): 383-87, April.

Sicular, T. and Zhao, Y. (2002a), "Employment, Eamings and Poverty in Rural China: A Mlicroeconomic Analysis", paper for the DRC/World Bank Conference on China's WTO Accession and Poverty Alleviation, Beijing, 28-29 June.

Sicular, T. and Zhao, Y. (2002b), 'Earnings and Labor Mobility in Rural China: Implications for China's WTO Entry', Mimeo.

Winters, I.A. (2000), "Trade, Trade Policy, and Poverty: What Are the Links?" CEPR Discussion Paper 2382, London: Centre for Economics Policy Research, March.

Yu, W. and S.E. Frandsen (2002), "China's WTO Commitments in Agriculture: Does the Impact Depend on OECD Agricultural Policies?" paper presented at the $5^{\text {th }}$ Conference on Global Economic Analysis, Taipei, 5-7 June.

Zhang, L., I. Huang and S. Rozelle. 2002. "Employment, Recessions, and the Role of Education in Rural China", China Economic Review, 114 (2002), pp: 1-16.

Zhao, Y. (1999), "Leaving the Countryside: Rural-to-Urban Migration Decision in China", American Economic Review 89(2): 281-86, May. 
Table 1: Growth rates of China's economy, 1970 to 2000 (per cent per year)

\begin{tabular}{lcccc}
\hline & Pre-reform & \multicolumn{3}{c}{ Reform period } \\
\cline { 5 - 5 } & $1970-78$ & $1979-84$ & $1985-95$ & $1996-00$ \\
\hline Gross domestic product & 4.9 & 8.8 & 9.7 & 7.9 \\
$\quad$ Agriculture & 2.7 & 7.1 & 4.0 & 3.4 \\
Industry & 6.8 & 8.2 & 12.8 & 9.6 \\
Service & $\mathrm{na}$ & 11.6 & 9.7 & 8.3 \\
& & & & \\
Food production volume & & & & \\
$\quad$ Grain & 2.8 & 4.7 & 1.7 & 0.03 \\
$\quad$ Oilseed crops & 2.1 & 14.9 & 4.4 & 5.6 \\
Fruit & 6.6 & 7.2 & 12.7 & 8.6 \\
Red meat & 4.4 & 9.1 & 8.8 & 6.5 \\
Fish & 5.0 & 7.9 & 13.7 & 10.2 \\
& & & & \\
Value of output of non-farm & & & & \\
rural enterprises & $\mathrm{na}$ & $\mathbf{1 2 . 3}$ & 24.1 & $\mathbf{1 4 . 0}$ \\
& & & & \\
Population & 1.80 & 1.15 & 1.43 & 0.91 \\
& & & & \\
Per capita GDP & 3.1 & 7.7 & 8.3 & 6.9 \\
\hline
\end{tabular}

Note: Figures for GDP in 1970-78 are the growth rate of national income in real terms. Growth rates are computed using the regression method. Growth rates of individual and groups of commodities are based on volume of production data, while sectoral growth rates refer to value added in real terms.

Source: SSB, Statistical Yearbook of China, various issues; MOA, Agricultural Yearbook of China, various issues. 
Table 2: Farm and rural enterprise (RE) developments in China, 1980 to 1999

\begin{tabular}{cccccc}
\hline & $\begin{array}{c}\text { RE's share } \\
\text { in rural } \\
\text { labor } \\
(\%)\end{array}$ & $\begin{array}{c}\text { RE's share } \\
\text { in total } \\
\text { GDP } \\
(\%)\end{array}$ & $\begin{array}{c}\text { RE's share } \\
\text { in total } \\
\text { export } \\
(\%)\end{array}$ & $\begin{array}{c}\text { Farm } \\
\text { land } \\
\text { size } \\
\text { (ha/farm) }\end{array}$ & $\begin{array}{c}\text { Non-farm } \\
\text { income } \\
\text { share } \\
(\%)\end{array}$ \\
\hline 1980 & 9 & 4 & 0 & 0.56 & 17 \\
1985 & 19 & 9 & 15 & 0.51 & 25 \\
1990 & 23 & 14 & 43 & 0.43 & 26 \\
1995 & 34 & 25 & 48 & 0.41 & 37 \\
1999 & 35 & 30 & 48 & 0.40 & 47 \\
\hline
\end{tabular}

Source: SSB, Statistical Yearbook of China, and China's TVE's Yearbook, various issues.

Table 3: The changing structure of China's economy, 1970 to 2000 (per cent, based on current prices)

\begin{tabular}{|c|c|c|c|c|c|c|}
\hline & 1970 & 1980 & 1985 & 1990 & 1995 & 2000 \\
\hline \multicolumn{7}{|l|}{ Share of $\mathbb{G D P}$} \\
\hline Agriculture & 40 & 30 & 28 & 27 & 20 & 16 \\
\hline Industry & 46 & 49 & 43 & $\Delta 2$ & 49 & 51 \\
\hline Services & 13 & 21 & 29 & 31 & 31 & 33 \\
\hline \multicolumn{7}{|l|}{ Share of employmemt } \\
\hline Agriculnure & 81 & 69 & 62 & 60 & 52 & 49 \\
\hline Industry & 10 & 18 & 21 & 21 & 23 & 23 \\
\hline Services & 9 & 13 & 17 & 19 & 25 & 28 \\
\hline \multicolumn{7}{|l|}{ Share of खgricunturral ountpurt } \\
\hline Crops & 82 & 76 & 69 & 65 & 58 & 56 \\
\hline Livestock & 14 & 18 & 22 & 26 & 30 & 30 \\
\hline Fish & 2 & 2 & 3 & 5 & 8 & 10 \\
\hline Forestry & 2 & 4 & 5 & 4 & 3 & 4 \\
\hline $\begin{array}{l}\text { Share of poppulatiom that is } \\
\text { rurral }\end{array}$ & 83 & 81 & 76 & 72 & 71 & 64 \\
\hline
\end{tabular}

Source: State Statistical Bureau, China Statistical Yearbook, various issues; and China Rural Statistical Yearbook, various issues. 
Table 4: China's grain production, consumption and trade, 1980 to 1998 (million tons)

\begin{tabular}{lccc}
\hline & $1980-89$ & $1990-94$ & $1995-98$ \\
\hline Production & 332 & 396 & 442 \\
Net imports & 8 & -1 & 6 \\
Change in stocks & 1 & 11 & 45 \\
Consumption & 339 & 384 & 403 \\
$\quad$ Food - urban & 35 & 42 & 44 \\
$\quad$ Food -- rural & 177 & 190 & 191 \\
$\quad$ Feed & 64 & 86 & 98 \\
$\quad$ Other (seed, industrial use, waste) & 63 & 66 & 70 \\
\hline
\end{tabular}

Source: Huang (2001), based on SSB publications and the CCAP database. 
Table 5: Structure of China's food and feed trade (US\$ million), 1980 to 1999

\begin{tabular}{|c|c|c|c|c|c|c|}
\hline & SITC & 1980 & 1985 & 1900 & 1995 & 1999 \\
\hline \multicolumn{7}{|l|}{ EXIPOIRTS: } \\
\hline Live animals & 00 & 384 & 304 & 430 & 473 & 374 \\
\hline Meat & 01 & 361 & 448 & 791 & 1,349 & 1,054 \\
\hline Dairy products & 02 & 71 & 57 & 55 & 61 & 71 \\
\hline Fish & 03 & 380 & 283 & 1,370 & 2,875 & 2,969 \\
\hline Grains & 04 & 423 & 1,065 & 614 & 281 & 1,273 \\
\hline Fruit and veg. & 05 & 746 & 825 & 1,759 & 3,399 & 3,150 \\
\hline Sugar & 06 & 221 & 79 & 317 & 321 & 214 \\
\hline Coffee and tea & 07 & 328 & 435 & 534 & 523 & 561 \\
\hline Animal feeds & 08 & 58 & 241 & 623 & 351 & 239 \\
\hline Other foods & 09 & 49 & 66 & 107 & 290 & 541 \\
\hline Oilseeds & 22 & na & na & na & 522 & 373 \\
\hline Vegetable oils & 4 & na & na & na & 454 & 132 \\
\hline TOTAL TFOOD & & $3, \mathbb{0 2 1}$ & 3,803 & $\varpi, \mathbb{G D}$ & $110, \$ 99$ & $110,15 \mathbb{1}$ \\
\hline \multicolumn{7}{|l|}{ IMIPOITS: } \\
\hline Live animals & 00 & 5 & 18 & 14 & 18 & 22 \\
\hline Meat & 01 & 1 & 6 & 54 & 97 & 503 \\
\hline Dairy products & 02 & 5 & 31 & 81 & 60 & 160 \\
\hline Fish & 03 & 13 & 44 & 102 & 609 & 890 \\
\hline Grains & 04 & 2,458 & 982 & 2,353 & 3,631 & 574 \\
\hline Fruit and veg. & 05 & 48 & 52 & 83 & 185 & 384 \\
\hline Sugar & 06 & 316 & 274 & 390 & 935 & 183 \\
\hline Coffee and tea & 07 & 56 & 40 & 30 & 74 & 72 \\
\hline Animal feeds & 08 & 14 & 83 & 182 & 423 & 620 \\
\hline Other foods & 09 & 2 & 23 & 46 & 92 & 182 \\
\hline Oilseeds & 22 & na & na & na & 110 & 1,531 \\
\hline Vegetable oils & 4 & na & na & na & 2,596 & 1,352 \\
\hline TOTAL FOOD & & 2,918 & 1,553 & 3,335 & $\$ 929$ & 6,867, \\
\hline \multicolumn{7}{|l|}{ NET EXIPORTS: } \\
\hline Live animals & 00 & 379 & 286 & 416 & 455 & 352 \\
\hline Meat & 01 & 360 & 442 & 737 & 1,252 & 551 \\
\hline Dairy products & 02 & 66 & 26 & -26 & 1 & -89 \\
\hline Fish & 03 & 367 & 239 & 1,268 & 2,266 & 2,079 \\
\hline Grains & 04 & $-2,035$ & 83 & $-1,939$ & $-3,350$ & 663 \\
\hline Fruit and veg. & 05 & 698 & 773 & 1,676 & 3,214 & 2,766 \\
\hline Sugar & 06 & -95 & -195 & -73 & -614 & 31 \\
\hline Coffee and tea & 07 & 272 & 395 & 504 & 449 & 489 \\
\hline Animal feeds & 08 & 44 & 158 & 441 & -72 & -381 \\
\hline Other foods & 09 & 47 & 43 & 61 & 198 & 359 \\
\hline Oilseeds & 22 & na & na & na & 412 & $-1,158$ \\
\hline Vegetable oils & 4 & na & $\mathrm{Na}$ & na & $-2,142$ & $-1,220$ \\
\hline TOTAI FOOD & & $1 \mathbb{1}$ & 2,250 & 3,265 & 2,071 & 0,077 \\
\hline
\end{tabular}

Source: Mathews (2002), based on UN COMTRADE statistics. 
Table 6: Nominal rates of protection (tariff or tariff equivalent), agricultural products, China, 1978 to 2000 , (per cent)

\begin{tabular}{|c|c|c|c|c|c|c|}
\hline & 1995 & 1997 & 2001 & $\begin{array}{c}2007 \\
\text { in-quota } \\
\text { tariff }\end{array}$ & $\begin{array}{c}2007 \\
\text { out-of- } \\
\text { quota tariff }\end{array}$ & $\begin{array}{l}\text { Assumed } \\
\text { NRP in } \\
2007 \text { (core } \\
\text { scenario) }\end{array}$ \\
\hline Rice & -5 & -5 & -3 & 1 & 65 & -3 \\
\hline Wheat & 25 & 17 & 12 & 1 & 65 & 12 \\
\hline Coarse grains & 20 & 28 & 20 & 1 & 65 & 32 \\
\hline Vegetables \& fruits & -10 & -8 & -4 & 11 & 11 & -4 \\
\hline Oilseeds & 30 & 28 & 32 & 3 & 3 & 3 \\
\hline Sugar & 44 & 42 & 40 & 15 & 50 & 20 \\
\hline Cotton & 20 & 17 & 17 & 1 & 40 & 20 \\
\hline Meats & -20 & -19 & -15 & 12 & 12 & -15 \\
\hline Milk & 30 & 30 & 30 & 11 & 11 & 11 \\
\hline
\end{tabular}

Source: Based on research subsequently reported in summary form in Huang and Rozelle (2002).

Table 7: Income, employment and agricultural output by region, China, 1998 and 2000

\begin{tabular}{|c|c|c|c|}
\hline & $\begin{array}{c}\text { Western } \\
\text { Provinces }\end{array}$ & $\begin{array}{c}\text { Central } \\
\text { Provinces }\end{array}$ & $\begin{array}{c}\text { Eastern } \\
\text { Provinces }\end{array}$ \\
\hline Income per capita (Yuan in 1998) & 4,090 & 5,280 & 9,690 \\
\hline Share of population that is rural (\% in 1998) & 81 & 75 & 71 \\
\hline Share of labor force in agriculture (\% in 1998$)$ & 64 & 55 & 45 \\
\hline Share of national agricultural GDP (\% in 2000 ) & 17 & 34 & 49 \\
\hline \multicolumn{4}{|l|}{$\begin{array}{l}\text { Share of regional food output ( } \% \text { in } 2000) \text { due } \\
\text { to: }\end{array}$} \\
\hline Rice & 8 & 11 & 6 \\
\hline Wheat & 5 & 5 & 4 \\
\hline Maize & 5 & 5 & 3 \\
\hline Vegetables and fruits & 11 & 10 & 14 \\
\hline Oilseeds & 4 & 6 & 3 \\
\hline Sugar & 0 & 0 & 1 \\
\hline Cotton & 3 & 2 & 1 \\
\hline Dairy products & 2 & 1 & 1 \\
\hline Other livestock products & 20 & 19 & 17 \\
\hline Fish products & 2 & 6 & 20 \\
\hline Other food, agricultural and forest products & 40 & 35 & 30 \\
\hline TOTAL & 100 & 100 & 100 \\
\hline
\end{tabular}

Source: Center for Chinese Agricultural Policy's CAPSIM Model and Carter and Estrin (2001). 
Table 8: Income and its distribution, rural and urban China, 1980 to 1999

\begin{tabular}{lcccccc}
\hline & \multicolumn{2}{c}{$\begin{array}{c}\text { Real per capita } \\
\text { income index }\end{array}$} & \multirow{2}{*}{$\begin{array}{c}\text { Gini } \\
\text { Year }\end{array}$} & Rural & $\begin{array}{c}\text { Poorest } \\
\text { Coefficient }\end{array}$ & \multicolumn{2}{c}{$\begin{array}{c}\text { Real per capita net income } \\
\text { (in 1999 yuan) }\end{array}$} \\
\cline { 7 - 8 } & & $20 \%$ & & & & \\
\hline 1980 & 100 & 100 & 0.24 & 616 & 2062 & 3.4 \\
1985 & 189 & 165 & 0.26 & 1193 & 2605 & 2.2 \\
1990 & 218 & 177 & 0.31 & 1380 & 3217 & 2.3 \\
1995 & 272 & 193 & 0.33 & 1702 & 4713 & 2.8 \\
1999 & 349 & 252 & 0.35 & 2210 & 5854 & 2.7 \\
\hline
\end{tabular}

Note: The exchange rate was 8.28 yuan/US\$ in 1999.

Source: SSB, 1989-2000, and rural household income and expenditure surveys. 
Table 9: Sectoral volume effects of China's WTO accession reforms (core case), 2002 to 2007 (per cent and 1997 US\$million)

\begin{tabular}{|c|c|c|c|c|c|c|c|}
\hline & Output & $\begin{array}{c}\text { Household } \\
\text { consumption }\end{array}$ & Exports & Imports & $\begin{array}{c}\text { Trade } \\
\text { Balance } \\
(\$ \mathrm{~m}) \\
\end{array}$ & $\begin{array}{c}\text { Producer } \\
\text { Prices }\end{array}$ & $\begin{array}{c}\text { Consumer } \\
\text { prices }\end{array}$ \\
\hline Rice & -2.1 & -0.1 & 6.1 & -7.1 & 64 & -0.9 & 0.9 \\
\hline Wheat & -2.0 & 0.0 & 18.9 & -10.1 & 174 & -1.7 & 0.4 \\
\hline Feedgrains & -2.3 & -0.1 & -77.8 & -2.4 & -596 & -1.9 & 1.9 \\
\hline Vegetables and fruits & -3.4 & 0.1 & 14.6 & -6.3 & 214 & -1.9 & -0.1 \\
\hline Oilseeds & -7.9 & 0.9 & 29.8 & 20.9 & -789 & -2.8 & -4.7 \\
\hline Sugar & -6.5 & 0.6 & 13.9 & 24.1 & -73 & -1.9 & -3.1 \\
\hline Plant based fibres & 15.8 & -0.6 & -51.8 & 7.7 & -189 & 0.1 & 3.1 \\
\hline Livestock \& meat & 1.3 & 0.0 & 15.5 & -8.9 & 837 & -1.6 & 0.2 \\
\hline Dairy & -2.0 & 0.0 & 13.5 & 23.8 & -143 & -1.5 & 0.2 \\
\hline Other food & -5.9 & 0.4 & 11.4 & 62.6 & -3460 & -1.7 & -1.8 \\
\hline Beverages \& tobacco & -33.0 & 1.5 & 9.7 & 112.4 & -14222 & -1.8 & -6.9 \\
\hline Extractive industries & -1.0 & -0.2 & 7.5 & -4.4 & 2088 & -0.7 & 1.2 \\
\hline Textiles & 15.6 & 0.7 & 32.7 & 38.5 & -10366 & -1.7 & -3.2 \\
\hline Apparel & 57.3 & 0.5 & 105.8 & 30.9 & 49690 & -0.5 & -1.9 \\
\hline Light manufacturing & 3.7 & 0.0 & 5.9 & 6.8 & 1786 & -0.9 & 0.0 \\
\hline Petrochemical industry & -2.3 & -0.2 & 3.1 & 11.8 & -8810 & -0.7 & 0.8 \\
\hline Metals & -2.1 & -0.3 & 3.7 & 6.8 & -1893 & -0.4 & 1.3 \\
\hline Autos & 1.4 & 1.0 & 27.7 & 24.0 & 516 & -3.9 & -4.2 \\
\hline Electronics & 0.6 & 0.5 & 6.7 & 6.8 & 453 & -1.3 & -1.7 \\
\hline Other manufactures & -2.1 & -0.2 & 4.1 & 18.9 & -11291 & -0.5 & 0.8 \\
\hline Trade and transport & 0.0 & -0.3 & 0.8 & -0.4 & 493 & -0.2 & 1.6 \\
\hline Construction & 0.9 & -0.4 & 2.7 & 17.5 & -436 & -0.2 & 1.7 \\
\hline Communication & -0.5 & -0.4 & -0.5 & 10.9 & -56 & 0.1 & 1.9 \\
\hline Commercial services & -2.0 & -0.5 & -0.4 & 35.4 & -1749 & 0.2 & 1.9 \\
\hline Other services & -1.7 & -0.3 & 1.4 & 33.6 & -1525 & -0.1 & 1.6 \\
\hline
\end{tabular}

Source: Authors' GTAP results. 
Table 10: Change in China's real factor prices and national economic welfare due to WTO accession, 2001 to 2007 (per cent, welfare in 1997 US\$ billions)

\begin{tabular}{|c|c|c|c|c|}
\hline & $\begin{array}{c}\text { Core } \\
\text { accession } \\
\text { case } \\
\end{array}$ & $\begin{array}{l}\text { Alternative 1: } \\
\text { greater } \\
\text { agricultural } \\
\text { protection cuts }\end{array}$ & $\begin{array}{c}\text { Alternative 2: } \\
\text { core case plus } \\
\text { also removing } \\
\text { negative agric } \\
\text { protection }\end{array}$ & $\begin{array}{l}\text { Alternative } 3 \text { : core } \\
\text { case plus also } \\
\text { removing labor } \\
\text { market distortion }\end{array}$ \\
\hline Farm unskilled wages & -0.7 & -0.9 & -0.5 & 16.8 \\
\hline Rental price of land & -5.5 & -6.4 & -4.7 & -9.7 \\
\hline Nonfarm unskilled wages & 1.2 & 1.4 & 1.1 & -3.8 \\
\hline Skilled labor wages & 0.8 & 1.0 & 1.5 & -1.7 \\
\hline Rental price of capital & 1.3 & 1.5 & 1.5 & -1.4 \\
\hline Farm household ${ }^{\mathrm{a}}$ income-A & -1.6 & -1.9 & -1.3 & 6.8 \\
\hline Farm household ${ }^{\mathrm{a}}$ income- $\mathrm{B}$ & -0.8 & -0.9 & -0.6 & 3.6 \\
\hline Farm household ${ }^{\mathrm{a}}$ income- $\mathbb{C}$ & 0.1 & 0.1 & 0.1 & 0.4 \\
\hline $\begin{array}{l}\text { National economic welfare } \\
\text { (\$ billion increase) }\end{array}$ & 9.56 & 9.57 & 9.87 & 11.05 \\
\hline
\end{tabular}

${ }^{a}$ Farm income from agriculture is made up of $57 \%$ from unskilled labor, $26 \%$ from land and $17 \%$ from capital, according to the GTAP database. In 1999 on average $51 \%$ of rural household income in China was earned outside agriculture, mostly from unskilled labor. Therefore, to illustrate the importance of those off-farm earnings, three types of farm households are shown in this table: it is assumed nonfarm unskilled labor contributes $0 \%$ of farm household income for type A, $30 \%$ for type B, and $60 \%$ for type $C$.

Source: Authors' GTAP results. 
Table 11: Effect on agricultural self sufficiency of China's WTO accession without and with cuts in agricultural protection in OECD countries (domestic production as a percentage of domestic consumption)

\begin{tabular}{lrrr}
\hline & $\begin{array}{r}\text { Base case (no } \\
\text { WTO accession } \\
\text { for China) }\end{array}$ & $\begin{array}{r}\text { China's WTO } \\
\text { accession with } \\
\text { no change in } \\
\text { OECD policies }\end{array}$ & $\begin{array}{r}\text { China's WTO accession } \\
\text { with EU, US and Japan } \\
\text { removing agric tariffs, } \\
\text { exports subsidies and } \\
\text { domestic support }\end{array}$ \\
\hline Rice & & & 99.6 \\
Wheat & 99.9 & 99.4 & 89.1 \\
Feedgrains & 93.0 & 88.2 & 99.6 \\
Vegetables and fruits & 98.1 & 98.1 & 99.9 \\
Oilseeds & 99.7 & 99.7 & 82.3 \\
Sugar & 81.0 & 81.3 & 82.9 \\
Plant-based fibres & 77.2 & 77.4 & 83.9 \\
Ruminant meat & 83.8 & 83.7 & 89.4 \\
Non-ruminant meat & 88.5 & 88.2 & 98.9 \\
Dairy products & 97.7 & 97.8 & 84.9 \\
\hline
\end{tabular}

Source: Yu and Frandsen (2002, Table 4). 
Appendix Table A: Cumulative (and annual) percentage growth rates over the period 1997-2007

\begin{tabular}{|c|c|c|c|c|c|}
\hline$\overline{\text { Regions }}$ & Population & $\begin{array}{l}\text { Unskilled } \\
\text { Labor }\end{array}$ & $\begin{array}{l}\text { Skilled } \\
\text { Labor }\end{array}$ & Capital & $\begin{array}{c}\text { Manufacturing } \\
\text { TFP }\end{array}$ \\
\hline North America & $\begin{array}{c}11 \\
(1.05)\end{array}$ & $\begin{array}{c}11 \\
(1.08)\end{array}$ & $\begin{array}{c}12 \\
(1.11)\end{array}$ & $\begin{array}{c}49 \\
(4.07)\end{array}$ & High \\
\hline Western Europe & $\begin{array}{c}0 \\
(0.03)\end{array}$ & $\begin{array}{c}-1 \\
(-0.08)\end{array}$ & $\begin{array}{c}1 \\
(0.07)\end{array}$ & $\begin{array}{c}30 \\
(2.69)\end{array}$ & High \\
\hline Australia/New Zealand & $\begin{array}{c}10 \\
(0.98)\end{array}$ & $\begin{array}{c}12 \\
(1.14)\end{array}$ & $\begin{array}{c}10 \\
(0.99)\end{array}$ & $\begin{array}{c}55 \\
(4.45)\end{array}$ & High \\
\hline Japan & $\begin{array}{c}1 \\
(0.06)\end{array}$ & $\begin{array}{c}-2 \\
(-0.19)\end{array}$ & $\begin{array}{c}-7 \\
(-0.71)\end{array}$ & $\begin{array}{c}35 \\
(3.02)\end{array}$ & Medium \\
\hline China & $\begin{array}{c}8 \\
(0.81)\end{array}$ & $\begin{array}{c}13 \\
(1.26)\end{array}$ & $\begin{array}{c}50 \\
(4.15)\end{array}$ & $\begin{array}{c}174 \\
(10.62)\end{array}$ & High \\
\hline Taiwan, China & $\begin{array}{c}9 \\
(0.86)\end{array}$ & $\begin{array}{c}11 \\
(1.05)\end{array}$ & $\begin{array}{c}14 \\
(1.36)\end{array}$ & $\begin{array}{c}96 \\
(6.97)\end{array}$ & High \\
\hline Other NICs & $\begin{array}{c}10 \\
(0.93)\end{array}$ & $\begin{array}{c}-1 \\
(-0.10)\end{array}$ & $\begin{array}{c}55 \\
(4.47)\end{array}$ & $\begin{array}{c}88 \\
(6.53)\end{array}$ & Medium \\
\hline Indonesia & $\begin{array}{c}16 \\
(1.50)\end{array}$ & $\begin{array}{c}17 \\
(1.59)\end{array}$ & $\begin{array}{c}123 \\
(8.36)\end{array}$ & $\begin{array}{c}25 \\
(2.27)\end{array}$ & Low \\
\hline Vietnam & $\begin{array}{c}15 \\
(1.40)\end{array}$ & $\begin{array}{c}32 \\
(2.79)\end{array}$ & $\begin{array}{c}36 \\
(3.10)\end{array}$ & $\begin{array}{c}111 \\
(7.78)\end{array}$ & Medium \\
\hline Other Southeast Asia & $\begin{array}{c}18 \\
(1.70)\end{array}$ & $\begin{array}{c}22 \\
(2.04)\end{array}$ & $\begin{array}{c}134 \\
(8.87)\end{array}$ & $\begin{array}{c}60 \\
(4.83)\end{array}$ & Low \\
\hline India & $\begin{array}{c}18 \\
(1.67)\end{array}$ & $\begin{array}{c}23 \\
(2.10)\end{array}$ & $\begin{array}{c}78 \\
(5.92)\end{array}$ & $\begin{array}{c}88 \\
(6.54)\end{array}$ & Medium \\
\hline Other South Asia & $\begin{array}{c}25 \\
(2.22)\end{array}$ & $\begin{array}{c}30 \\
(2.69)\end{array}$ & $\begin{array}{c}80 \\
(6.06)\end{array}$ & $\begin{array}{c}72 \\
(5.55)\end{array}$ & Medium \\
\hline Brazil & $\begin{array}{c}14 \\
(1.31)\end{array}$ & $\begin{array}{c}19 \\
(1.77)\end{array}$ & $\begin{array}{c}72 \\
(5.60)\end{array}$ & $\begin{array}{c}31 \\
(2.75)\end{array}$ & Medium \\
\hline Other Latin America & $\begin{array}{c}18 \\
(1.68)\end{array}$ & $\begin{array}{c}6 \\
(0.57)\end{array}$ & $\begin{array}{c}90 \\
(6.65)\end{array}$ & $\begin{array}{c}54 \\
(4.42)\end{array}$ & Low \\
\hline Turkey & $\begin{array}{c}16 \\
(1.47)\end{array}$ & $\begin{array}{c}19 \\
(1.75)\end{array}$ & $\begin{array}{c}107 \\
(7.55)\end{array}$ & $\begin{array}{c}55 \\
(4.46)\end{array}$ & Low \\
\hline Other Middle East \& North Africa & $\begin{array}{c}24 \\
(2.16)\end{array}$ & $\begin{array}{c}37 \\
(3.23)\end{array}$ & $\begin{array}{c}67 \\
(5.24)\end{array}$ & $\begin{array}{c}28 \\
(2.50)\end{array}$ & Low \\
\hline Economies in Transition & $\begin{array}{c}-1 \\
(-0.11)\end{array}$ & $\begin{array}{c}6 \\
(0.56)\end{array}$ & $\begin{array}{c}9 \\
(0.90)\end{array}$ & $\begin{array}{c}33 \\
(2.88)\end{array}$ & High \\
\hline South African Customs Union & $\begin{array}{c}15 \\
(1.39)\end{array}$ & $\begin{array}{c}31 \\
(2.76)\end{array}$ & $\begin{array}{c}47 \\
(3.92)\end{array}$ & $\begin{array}{c}34 \\
(2.94)\end{array}$ & Low \\
\hline Other Sub-Saharan Africa & $\begin{array}{c}30 \\
(2.65)\end{array}$ & $\begin{array}{c}40 \\
(3.42)\end{array}$ & $\begin{array}{c}54 \\
(4.42)\end{array}$ & $\begin{array}{c}38 \\
(3.26)\end{array}$ & Medium \\
\hline Rest of World & $\begin{array}{c}18 \\
(1.63)\end{array}$ & $\begin{array}{c}23 \\
(2.10)\end{array}$ & $\begin{array}{c}35 \\
(3.05)\end{array}$ & $\begin{array}{c}68 \\
(5.32)\end{array}$ & Low \\
\hline
\end{tabular}

\#The low, medium, and high growth assumptions for total factor productivity (TFP) in manufacturing correspond to annual growth rates of $0.1 \%, 1.0 \%$, and above $2.0 \%$ (between $2 \%$ and $4 \%$ ), respectively.

Source: Ianchovichina and Martin (2002) 




\begin{tabular}{|c|c|c|c|c|}
\hline & Title & Author & Date & $\begin{array}{l}\text { Contact } \\
\text { for paper }\end{array}$ \\
\hline WPS3027 & $\begin{array}{l}\text { Financial Intermediation and Growth: } \\
\text { Chınese Style }\end{array}$ & $\begin{array}{l}\text { Genevieve Boyreau- } \\
\text { Debray }\end{array}$ & April 2003 & $\begin{array}{l}\text { P Sintim-Aboagye } \\
38526\end{array}$ \\
\hline WPS3028 & $\begin{array}{l}\text { Does a Country Need a Promotion } \\
\text { Agency to Attract Foreign Direct } \\
\text { Investment? A Small Analytical Model } \\
\text { Applied to } 58 \text { Countries }\end{array}$ & Jacques Morisset & April 2003 & $\begin{array}{l}\text { M. Feghali } \\
36177\end{array}$ \\
\hline WPS3029 & $\begin{array}{l}\text { Who Benefits and How Much? How } \\
\text { Gender Affects Welfare Impacts of a } \\
\text { Booming Textile Industry }\end{array}$ & $\begin{array}{l}\text { Alessandro Nicita } \\
\text { Susan Razzaz }\end{array}$ & April 2003 & $\begin{array}{l}\text { P Flewitt } \\
32724\end{array}$ \\
\hline WPS3030 & $\begin{array}{l}\text { The Impact of Bank Regulations, } \\
\text { Concentration, and Institutions on } \\
\text { Bank Margins }\end{array}$ & $\begin{array}{l}\text { Asl1 Demırgüç-Kunt } \\
\text { Luc Laeven } \\
\text { Ross Levine }\end{array}$ & April 2003 & $\begin{array}{l}\text { A. Yaptenco } \\
31823\end{array}$ \\
\hline WPS3031 & $\begin{array}{l}\text { Imports, Entry, and Competition Law } \\
\text { as Market Disciplines }\end{array}$ & $\begin{array}{l}\text { Hiau Looi Kee } \\
\text { Bernard Hoekman }\end{array}$ & April 2003 & $\begin{array}{l}\text { P Flewitt } \\
32724\end{array}$ \\
\hline WPS3032 & $\begin{array}{l}\text { Information Diffusion in International } \\
\text { Markets }\end{array}$ & $\begin{array}{l}\text { Alejandro Izquierdo } \\
\text { Jacques Morisset } \\
\text { Marcelo Olarreaga }\end{array}$ & April 2003 & $\begin{array}{l}\text { M Feghali } \\
36177\end{array}$ \\
\hline WPS3033 & $\begin{array}{l}\text { The Role of Occupational Pension } \\
\text { Funds in Mauritus }\end{array}$ & Dimitri Vittas & April 2003 & $\begin{array}{l}\text { P. Infante } \\
37642\end{array}$ \\
\hline WPS3034 & $\begin{array}{l}\text { The Insurance Industry in } \\
\text { Mauritius }\end{array}$ & Dimitri Vittas & April 2003 & $\begin{array}{l}\text { P. Infante } \\
37642\end{array}$ \\
\hline WPS3035 & $\begin{array}{l}\text { Traffic Fatalities and Economic } \\
\text { Growth }\end{array}$ & $\begin{array}{l}\text { Elizabeth Kopits } \\
\text { Maureen Cropper }\end{array}$ & April 2003 & $\begin{array}{l}\text { V. Soukhanov } \\
35721\end{array}$ \\
\hline WPS3036 & $\begin{array}{l}\text { Telecommunications Reform in } \\
\text { Malawi }\end{array}$ & $\begin{array}{l}\text { George R. G Clarke } \\
\text { Frew A Gebreab } \\
\text { Henry R. Mgombelo }\end{array}$ & April 2003 & $\begin{array}{l}\text { P. Sintim-Aboagye } \\
37644\end{array}$ \\
\hline WPS3037 & $\begin{array}{l}\text { Regulation and Private Sector } \\
\text { Investment in Infrastructure. } \\
\text { Evidence from Latin America }\end{array}$ & Sheoli Pargal & April 2003 & $\begin{array}{l}\text { S. Pargal } \\
81951\end{array}$ \\
\hline WPS3038 & $\begin{array}{l}\text { The Debate on Globalization, } \\
\text { Poverty, and Inequality: Why } \\
\text { Measurement Matters }\end{array}$ & Martın Ravallion & May 2003 & $\begin{array}{l}\text { P. Sader } \\
33902\end{array}$ \\
\hline WPS3039 & $\begin{array}{l}\text { Scaling Up Community-Driven } \\
\text { Development: Theoretical } \\
\text { Underpinnings and Program Design } \\
\text { Implications }\end{array}$ & $\begin{array}{l}\text { Hans P. Binswanger } \\
\text { Swaminathan S. Aiyar }\end{array}$ & May 2003 & $\begin{array}{l}\text { T Nguyen } \\
31389\end{array}$ \\
\hline WPS3040 ! & $\begin{array}{l}\text { Household Welfare Impacts of } \\
\text { China's Accession to the World } \\
\text { Trade Organization }\end{array}$ & $\begin{array}{l}\text { Shaohua Chen } \\
\text { Martin Ravallıon }\end{array}$ & May 2003 & $\begin{array}{l}\text { P. Sader } \\
33902\end{array}$ \\
\hline WPS3041 & Bank Concentration and Crises & $\begin{array}{l}\text { Thorsten Beck } \\
\text { Asl1 Demirgüç-Kunt } \\
\text { Ross Levine }\end{array}$ & May 2003 & $\begin{array}{l}\text { K. Labrie } \\
31001\end{array}$ \\
\hline WPS3042 & $\begin{array}{l}\text { Bank Supervision and Corporate } \\
\text { Finance }\end{array}$ & $\begin{array}{l}\text { Thorsten Beck } \\
\text { Asl1 Demirgüç-Kunt } \\
\text { Ross Levine }\end{array}$ & May 2003 & $\begin{array}{l}\text { K. Labrie } \\
31001\end{array}$ \\
\hline
\end{tabular}


Policy Research Working Paper Series

Tîte

WPS3043 The Incentive-Compatible Design of Deposit Insurance and Bank Failure Resolution Concepts and Country Studies

WPS3044 Impregnated Nets Cannot Fully Substitute for DDT: Field Effectiveness of Malaria Prevention in Solomon Islands

WPS3045 Causes and Consequences of Civil Strife: Micro-Level Evidence from Uganda

WPS3046 Migration, Spillovers, and Trade Diversion: The Impact of Internatıonalization on Stock Market Liquidity

WPS3047 Comparing Mortgage Credit Risk Policies: An Options-Based Approach

Robert Buckley

Bernard Bakote'e

Raman Velayudhan

Peter Wilikai

Patricia M. Graves

Klaus Deinınger

Ross Levine

Sergio L. Schmukler

Robert Van Order

Laura Vecvagare

WPS3048 Targeted Transfers in Poor Countries: Martin Ravallıon Revisiting the Tradeoffs and Policy Options

WPS3049 Hidden Impact? Ex-Post Evaluation of an Anti-Poverty Program

Shaohua Chen

Martin Ravallıon

Wafık Graıs

WPS3050 The Changing FInancial LandscapeOpportunities and Challenges for the Middle East and North Africa

WPS3051 Regional, Multilateral, and Unilateral Trade Policies of MERCOSUR for Growth and Poverty Reduction in Brazil
May 2003

37471

May 2003

0 Himid 80225

Contact

for paper

K. Labrie

31001

H Sladovich

37698

M. Fernandez 33766

E. Khıne

P. Sader

May 2003

33902

May 2003

P. Sader 33902

May 2003

R. Vo

33722

May 2003

P. Flewitt 32724
Thomas F. Rutherford

David G Tarr

Angelo Gurgel 